\title{
Management of carcinoma of the penis: Consensus statement from the Canadian Association of Genitourinary Medical Oncologists (CAGMO)
}

\author{
Suzanne Richter, MD, MSc, FRCPC,; J. Dean Ruether, MD,; Lori Wood, MD, MSc; ${ }_{\text {; }}^{+}$Christina Canil, MD, FRCPC; \\ Patricia Moretto, MD; $;$ Peter Venner, MD; Joel Gingerich, MD, FRCPC, ${ }^{\ddagger}$ Urban Emmenegger, MD; ${ }^{a}$ \\ Andrea Eisen, MD, FRCPC;, Pawel Zalewski, MD, FRCPC; ${ }^{-1}$ Anthony Joshua, MBBS, PhD, FRACP; ${ }^{*}$ \\ Som Dave Mukherjee, MD, MSc, FRCPC,; Daniel Heng, MD, ${ }^{3}$ Piotr Czaykowski, MD, MSc, FRCPC, \\ Denis Soulieres, MD, ${ }^{4}$ Norman Blais, MD, MSc, ${ }^{4}$ Ricardo Rendon, MD, FRCSC, ${ }^{5}$ Neil Fleshner, MD, FRCSC, MPH; \\ Juanita M. Crook, MD, FRCPC, ${ }^{6}$ Srikala S. Sridhar, MD, MSc, FRCPC
}

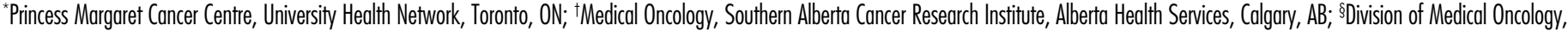
Queen Elizabeth II Heath Sciences Centre, Halifax, NS; *Department of Medicine, Division of Medical Oncology, The Ottawa Hospital Cancer Centre; and The Ottawa Hospital Research Institute, University of Ottawa, Ottawa, ON; ${ }^{ \pm}$Department of Oncology, University of Alberta, Cross Cancer Institute, Edmonton, AB; ‘ Eivision of Medical Oncology, Cancer Care Manitoba, University of Manitoba, Winnipeg, MB; -Division of Medical Oncology, Odette Cancer Centre, Sunnybrook Research Institute, Toronto, ON; 'Division of Oncology, Lakeridge Health Centre, Toronto, ON; ${ }^{2}$ Division of Medical Oncology, Juravinski Cancer Centre, Hamilton, ON; ${ }^{3}$ Alberta Health Services, AB; ${ }^{4}$ Hematology and Medical Oncology Service, Department of Medicine, Centre Hospitalier de I'Universite de Montreal, Montreal, Montreal, QC; ${ }^{5}$ Department of Surgery, Dalhousie University, Halifax, NS; ${ }^{B}$ BC Cancer Agency Sindi Ahluwalia Hawkins Centre for the Southern Interior, Kelowna, BC
\end{abstract}

Cite as: Can Urol Assoc J 2013;7(11-12):e797-811. http://dx.doi.org/10.5489/cuaj.1794 Published online December 5, 2013.

\section{Introduction}

Penile cancer occurs in about 1 in 100000 men annually in developed countries. ${ }^{1}$ In Canada, penile cancer is reported under "genito-urinary, other and unspecified" in the annual Cancer Statistics and accounts for about 200 new cases and 30 related deaths. ${ }^{2}$ Similarly, the American Cancer Society statistics for 2011 estimated 1360 new cases and 320 penile cancer-related deaths. ${ }^{3}$

Penile cancer most commonly affects men between the ages of 65 to 74 years, and presents with well or moderately differentiated disease. Although most cases are localized, about $25 \%$ of patients will have regional involvement and $4 \%$ will have distant disease at the time of diagnosis. ${ }^{1}$ The most powerful prognostic indicator in the absence of distant disease is nodal involvement. The 5 -year survival rate for carcinoma in situ is over $90 \%$, but drops to $60 \%$ with nodal involvement and to $20 \%$ for patients with metastatic disease. ${ }^{4,5}$

Due to the low incidence of this disease, management is often guided by case reports, small case series and local experience. No Canadian guidelines or consensus statements currently exist to guide the diagnosis and management of these patients. The European Association of Urology (EAU) has published guidelines on the management approach to penile cancer, but recent data published by Johnson and collegues $^{6}$ suggest that these recommendations have not been widely applied in North America. ${ }^{5,6}$
Our objective was to develop the first Canadian Consensus Statement on the management of penile cancer for Canadian oncologic specialists treating genitourinary cancers based on available evidence, existing guidelines and expert Canadian opinion to better address the needs of patients with penile cancer in Canada.

\section{Methodology}

In June 2011, a group of Canadian genitourinary medical oncologists attended the annual Canadian Genitourinary Medical Oncology (CAGMO) meeting to discuss the management of penile cancer. Key references, including the EUA guidelines and provincial guidelines (British Columbia and Alberta), were reviewed. The modified version of the Oxford Levels of Evidence and Recommendation Grading ${ }^{7}$ (Table 1) was used to grade the evidence and recommendations. Surgical approaches were reviewed but not graded. A search of MEDLINE, Cochrane and EMBASE databases (Jan 1988-Feb 2012) was included to evaluate data; we also reviewed the recent guidelines from the EUA, ${ }^{5}$ National Comprehensive Network Cancer ${ }^{8}$ and the International Consultation on Penile Cancer. ${ }^{4}$ Search terms included penile cancer or cancer of the penis or carcinoma of the penis or penile carcinoma with systemic therapy or chemotherapy as the topic of interest with an English language limit. Retrospective and prospective study designs which evaluated progression-free survival or overall survival benefit of systemic therapy in 10 or more individuals with squamous cell carcinoma of the penis were included. Opinion from Canadian experts in medical oncology, radiation oncology, 


\begin{tabular}{|c|c|c|c|}
\hline Grade & Definition & Levels & \\
\hline A & Consistent level 1 & 1 & $\begin{array}{l}\text { Systematic review of } \\
\text { randomized trials }\end{array}$ \\
\hline B & $\begin{array}{c}\text { Consistent level } 2 \text { or } \\
\text { extrapolation from level } 1 \\
\text { or } 3 \text { studies }\end{array}$ & 2 & $\begin{array}{c}\text { Individual } \\
\text { randomized trial }\end{array}$ \\
\hline C & $\begin{array}{c}\text { Level } 4 \text { studies or } \\
\text { extrapolation from level } 2 \\
\text { or } 3 \text { studies }\end{array}$ & 3 & Controlled cohort \\
\hline \multirow[t]{2}{*}{$\mathrm{D}$} & $\begin{array}{l}\text { Level } 5 \text { evidence or } \\
\text { inconsistent/inconclusive } \\
\text { studies of any level }\end{array}$ & 4 & $\begin{array}{l}\text { Case series or case } \\
\text { control studies }\end{array}$ \\
\hline & & 5 & $\begin{array}{l}\text { Mechanism based } \\
\text { reasoning }\end{array}$ \\
\hline
\end{tabular}

and uro-oncology was also incorporated into the consensus statement. The manuscript was evaluated using the AGREEII instrument. ${ }^{9}$ A planned update will occur in 5 years.

\section{Penile cancer risk factors}

The main risk factors for penile cancer with an odds ratio $>10$ include phimosis, chronic inflammatory conditions of the penis, treatment with psoralen and ultraviolet A phototherapy, a history of multiple sexual partners, and early age at first intercourse. ${ }^{10}$ History of condylomata is associated with a 6 -fold increase in the risk of penile cancer. ${ }^{10}$ History of smoking is associated with a 3- to 4.5-fold increase in risk and is an independent risk factor regardless of sexual history. ${ }^{10}$

\section{Circumcision}

Circumcision is a controversial issue that weighs the rights for individual choice and potential for disease prevention against the risk of complications and cost-effectiveness of a population-based program. Although several series and a meta-analysis support a reduction in both Human papilloma virus (HPV) and penile cancer prevalence with circumcision, ${ }^{11-14}$ routine neonatal circumcision has been delisted in every province across Canada due to an unfavourable benefit-to-harm ratio.

\section{Human papilloma virus and vaccination}

HPV prevalence in penile cancer is about $50 \%$, with a presumed link to causality in a recent large systematic review. ${ }^{15}$ The serotypes commonly associated with other anogenital malignancies are also most frequent in men with penile cancer, including HPV16 (60\%) and HPV18 (13\%). In contrast, the incidence of HPV infection on the foreskin of unaffected men is 0 to $6 \%{ }^{15,16}$

The role for vaccination against HPV and associated conditions remains controversial. The quadrivalent vaccine
HPV4 (Gardasil, Merck \& Co.) is directed against HPV6, 11,16 , and 18. The bivalent HPV2 vaccine (Cervarix, GlaxoSmithKline) is directed against HPV16 and 18. Both vaccines are approved by Health Canada for use in females. The HPV4 vaccine is FDA-licensed for use in males to protect against genital warts and anal cancer. In 2010, Health Canada approved the HPV4 vaccine for males aged 9 to 26 years old. However to date, no province has implemented routine male vaccination.

The impact of vaccination on early penile cancer lesions was one of several endpoints in a recent clinical trial. In the phase III randomized, placebo-controlled trial of HPV $4,{ }^{17}$ no statistically significant effect against grade 1 to grade 3 penile intraepithelial neoplasia was demonstrated. The limitations of this trial include the narrow participant age-range and a current short follow-up period of 2.9 years.

\section{HIV}

Penile cancer is increased 8-fold in individuals affected by HIV. ${ }^{18}$ The reason for this observation is not fully elucidated and may be due to increased incidence of HPV infection. ${ }^{18}$

\section{Staging of the primary}

\section{Clinical staging of the primary}

Penile carcinoma often presents with a visible or palpable lesion that may be accompanied by pain, bleeding or discharge. Often these lesions are hidden under a phimotic foreskin which can delay diagnosis. A high index of suspicion is required in the setting of a penile lesion or if there is a history of bleeding or discharge from a non-retractile foreskin.

Staging of the primary lesion includes physical examination with attention to morphologic appearance, location, and extent. Magnetic resonance imaging (MRI) of the penis with prostaglandin E1-induced erection is considered one of the most sensitive imaging modality to date to determine the depth of corporal invasion. ${ }^{19}$ Ultrasound may also serve as an adjunct to physical examination for determining infiltration into the corpus cavernosum. ${ }^{20}$ Computed tomography (CT) imaging is not sufficient to determine the depth of tumour penetration locally, but it is useful to detect enlarged lymph nodes. $^{21}$

\section{Pathological reporting of the primary}

At presentation, excisional biopsy is favoured. However if a diagnostic biopsy is performed, this must often be preceded by either a dorsal slit of the foreskin or circumcision to expose the lesion. 
Penile cancer is predominantly of squamous cell histology $(95 \%)$ with several subtypes, including verrucous carcinoma, basaloid carcinoma, warty carcinoma (verruciform), and neuroendocrine carcinoma. Malignant melanoma and basal cell carcinoma account for the remainder of penile cancer cases. ${ }^{22}$ Among the different histologies, sarcomatoid variants have the worst prognosis, with an $89 \%$ risk of lymph node invasion. ${ }^{23}$ The main components in a pathology report should include: anatomic site, tumour size, histologic type, ${ }^{24}$ grade, ${ }^{25}$ growth pattern, ${ }^{26}$ invasive front,${ }^{27}$ depth of invasion, tumour thickness, resection margins, lymphovascular invasion, and perineural invasion. ${ }^{28}$ These components play a critical role in determining both prognosis and treatment.

Penile cancer is staged according to the American Joint Committee on Cancer (AJCC) Tumour, Node, Metastases (TNM) guidelines (Table 2). ${ }^{29}$ Important changes in the recent 2010 publication of AJCC TNM guidelines include the distinction between $\mathrm{T} 1 \mathrm{a}$ and $\mathrm{T} 1 \mathrm{~b}$ lesions. T1a lesions are defined by grade 1 or 2 histology and by the absence of lymphovascular invasion. T1b lesions are defined by grade 3 or 4 histology or the presence of lymphovascular invasion. The significance of differentiating these lower risk lesions from their higher risk counterparts is to better identify those patients who may benefit from early lymph node dissection in the setting of clinically negative inguinal lymph nodes. Other important changes include the upgrading of prostatic invasion to category T4 and any lymph node involvement to at least a stage III (Box 1).

\section{Box 1. Staging of the penile primary \\ Recommendations \\ 1. Clinical staging of the primary requires physical examination of the penis to determine extent of involvement. Imaging may be considered helpful in further delineating involvement. When imaging is considered, either MRI or ultrasound should be used (Grade C).}

2. Pathologic reporting should adhere to the most recent AJCC guidelines.

\section{Staging the lymph nodes}

\section{Clinical uninvolved lymph nodes}

In penile cancer, lymph node involvement (in the absence of distant disease) is the most powerful prognostic indicator. Regional spread occurs from the inguinal nodes to the pelvic lymph nodes. ${ }^{30}$ Physical examination of the inguinal nodes therefore must be performed. At the time of diagnosis, about $50 \%$ of patients will have palpable nodes. In half of these men, the adenopathy is related to metastatic disease. ${ }^{31}$ The evidence for lymph node management was

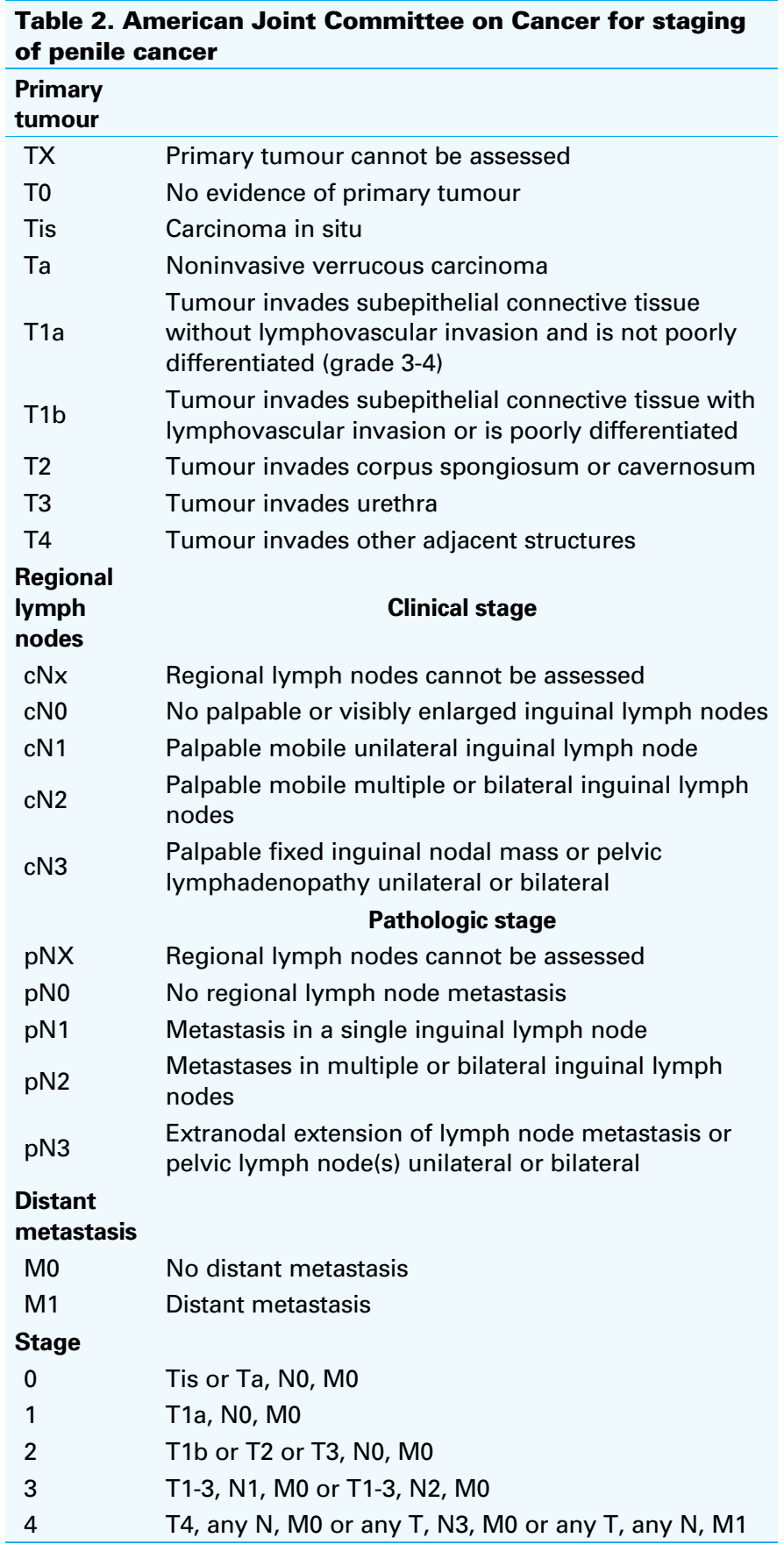

recently reviewed ${ }^{32}$ and showed that clinically abnormal lymph nodes may require a different management strategy than those that are clinically negative.

The lymph nodes are clinically staged on the basis of palpable inguinal lymphadenopathy. An assessment of the number of nodes involved, size, laterality, and mobility should be performed. ${ }^{29}$ Ultrasound has some value identifying metastatic lymph nodes based on architectural change and can increase the diagnostic yield for metastases greater than $2 \mathrm{~mm} .{ }^{4}$ In some cases, the ability to palpate inguinal 
lymph nodes is hampered by body mass index and prior treatment. In a thin patient, normal inguinal lymph nodes may be readily palpable. In obese men, the clinical exam may be supplemented by imaging. The European Association of Urology (EAU) reports that CT imaging is used most commonly for imaging the inguinal lymph nodes despite a low sensitivity of $36 \% .^{5}$ A CT is valuable in identifying high-risk patients based on the presence of central node necrosis and irregular borders. ${ }^{33}$ Lymphotropic nanoparticle-enhanced $\mathrm{MRI}^{34}$ demonstrated high sensitivity (100\%) and specificity $(97 \%)$, with a positive predictive value of $81.2 \%$ for micrometastatic disease. This encouraging data, however, were generated in a small sample size and remain dependent on institutional expertise. Similarly, a positron emission tomography (PET) scan was shown to have a positive predictive value of $94 \%$ and a negative predictive value of $96 \%$. These data were generated in a 2012 prospective trial evaluating 35 patients; ${ }^{35}$ this trial suggested the possible utility of penile cancer staging, but the topic warrants further prospective evaluation in larger studies. Currently, MRI is a reasonable choice to supplement physical exam in individuals in whom access to the inguinal regions is difficult; it also allows for concurrent evaluation of the primary. ${ }^{36}$

Dynamic sentinel node biopsy (DSNB) is a newer technique to assess clinically uninvolved nodes. Three important points are acknowledged: (1) The false negative rate for DSNB is $20 \%$ to $30 \% ;{ }^{37,38}$ (2) DSNB may not be reliable for palpable lymph nodes that may be entirely replaced by a tumour; ${ }^{39}$ and (3) DSNB is not readily available in Canada.

\section{Clinically involved lymph nodes}

If an inguinal lymph node is palpable and considered suspicious, the diagnosis should be confirmed by fine needle aspiration (FNA). ${ }^{40}$ Repeat biopsy is advised when the FNA is negative and the clinical suspicion is high. ${ }^{41} \mathrm{~A}$ prolonged trial of antibiotics is no longer considered appropriate. Individuals with histologically positive nodes should undergo therapeutic ipsilateral radical inguinal lymph node dissection, ${ }^{42}$ with modified dissection on the contralateral side. Surgical staging is also an option, with complete inguinal lymph node dissection conferring a possible therapeutic benefit with the potential for cure (discussed further under the management section). A suggested algorithm based on the presence of clinically involved lymph nodes is shown in Fig. 1.

In the setting of palpable inguinal adenopathy, abdominopelvic imaging may detect the location and the extent of involved nodes, pelvic and retroperitoneal lymphadenopathy, as well as distant disease (Box 2). ${ }^{40,43}$

\section{Box 2. Staging of the lymph nodes}

\section{Recommendations}

Clinical staging of the inguinal lymph nodes requires physical examination. Ultrasound with fine needle aspiration can increase the diagnostic yield in individuals with palpable nodes (Grade C).

Physical examination in individuals with clinically uninvolved nodes can be supplemented by MRI, CT or PET in individuals where clinical assessment alone is difficult (Grade C).

Abdominopelvic imaging in individuals with clinically involved nodes can assess the presence of pelvic and retroperitoneal lymph nodes (Grade C).

\section{Surgical management of the penile primary tumour}

\section{Stage Tis, Ta}

Tis and Ta are in situ and noninvasive lesions, respectively. Treatment options include local excision with or without circumcision, ${ }^{44}$ carbon dioxide or neodymidium:yttriumaluminum-garnet ( $\mathrm{Nd}$ :YAG) laser therapy, ${ }^{45}$ and photodynamic therapy. ${ }^{46}$ Verrucous carcinoma can be treated with Mohs micrographic surgery; ${ }^{47}$ recurrent superficial lesions may be treated with 5 -fluorouracil or $5 \%$ imiquimod cream as topical therapy. ${ }^{48}$ There are no clinical trials or comparative studies to indicate which approach is superior. The key concept is that superficial disease should be managed by penile-sparing approaches, lessening the negative impact of treatment on quality of life..$^{49}$ Treatment decisions are guided by tumour features, local expertise, and patient preference.

\section{Stage Tl}

Category T1a lesions limited to the foreskin are superficial and can be managed by the same conservative approaches used in Tis and Ta disease. Category T1b lesions are now a distinct group from their T1a counterparts in the most recent AJCC staging system to differentiate lesions that, on the basis of high histologic grade (Grade 3-4) or lymphovascular invasion, are more likely to be associated with inguinal lymph node involvement. Since these T1b lesions are also upstaged to stage 2, more aggressive approaches are indicated. Surgical options include partial penectomy or glansectomy. ${ }^{50}$ For smaller lesions, neoadjuvant chemotherapy (including vinblastine, bleomycin, and methotrexate) followed by $\mathrm{CO} 2$ laser excision ${ }^{51}$ has been reported, but is not commonly used in Canada. Radiotherapy for lesions under $4 \mathrm{~cm}$ can be used. ${ }^{52-54}$ Further discussion is found in the radiation section. Careful follow-up for local recurrences is required. 


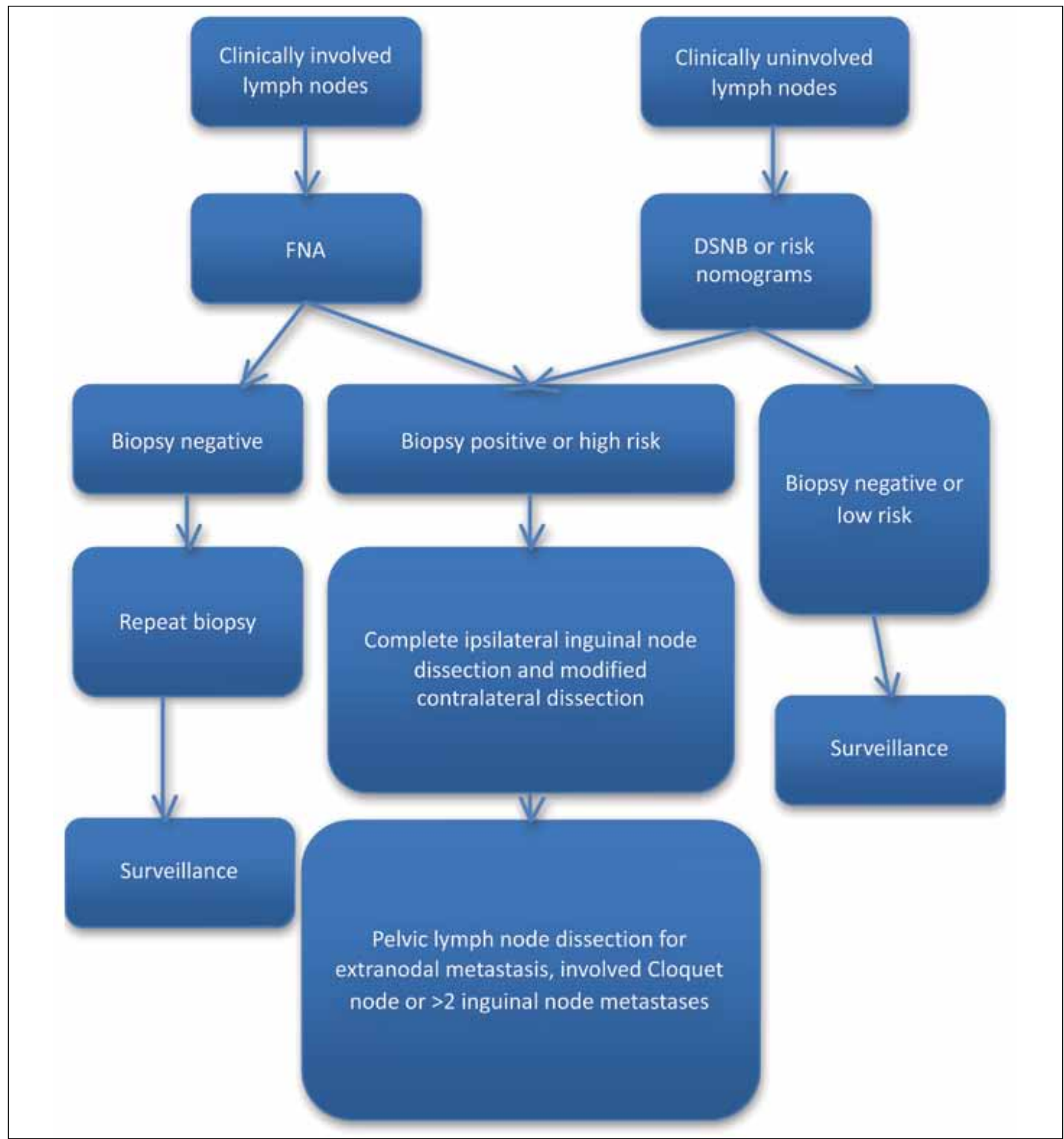

Fig. 1. Algorithm for management of the inguinal lymph nodes. FNA: fine needle aspiration; DSNB: dynamic sentinel node biopsy.

\section{Stage T2}

In individuals with T2 disease limited to the glans, surgical options include total glansectomy with or without resurfac- ing of the corporeal heads. It is appropriate to selectively use partial glansectomy in patients with no urethral invasion and patients amenable to close monitoring for local recurrence. ${ }^{50}$ Partial penectomy should be considered where more conservative reconstructive surgery is not appropriate or for large 
tumours involving more than the distal corpora. ${ }^{55} \mathrm{Although}$ the traditional 2-cm proximal margin allows for disease control while preserving voiding function, more recent data suggest that a 5 to $10-\mathrm{mm}$ margin may be sufficient. ${ }^{56}$ Radiation, either as brachytherapy or external beam, is an alternative to surgical approaches and, similar to T1 lesions, is best used for lesion under $4 \mathrm{~cm}$ (see section Radiation).

Within the T2 category, cavernosal involvement may portend a worse prognosis than spongiosum involvement alone. ${ }^{57}$ However, to date, this distinction is not reflected in the AJCC staging guidelines.

\section{Stage $\mathrm{T} 3$ and $\mathrm{T} 4$}

Total penectomy with perineal urethrostomy is standard for T3 tumours and is recommended by the EAU. ${ }^{5}$ In T4 disease, most patients will have fixed inguinal and involved pelvic lymph nodes with a poor prognosis. Neoadjuvant chemotherapy (discussed specifically in the Chemotherapy section) or chemoradiotherapy (discussed in the Radiation section) should be considered. In the absence of neoadjuvant therapy, adjuvant chemotherapy or consolidation with radiation therapy is suggested by the EAU and is discussed further in the respective sections (Box 3 ).

\section{Box 3. Surgical management of the primary tumour \\ Recommendations \\ Penile preserving approaches should be considered for Tis-Ta and T1 disease in the absence of grade 3 or more histology to balance local recurrence rates, maintenance of function and quality of life. (Grade B).}

Total penectomy with perineal urethrostomy is recommended for T3 lesions (Grade B).

Neoadjuvant chemotherapy or chemo-radiotherapy is advised prior to surgery for T4 lesions (Grade C).

\section{Surgical management of the lymph nodes}

\section{Clinically involved lymph nodes}

Individuals with clinically suspicious lymph nodes should undergo fine needle aspiration/cytology. Those individuals with histologically confirmed lymphadenopathy under $4 \mathrm{~cm}$ should undergo ispilateral lymph node dissection and a contralateral staging superficial inguinal node dissection. Further surgery can be based on the findings from this primary surgery (see Pelvic lymph nodes section). Individuals with multiple or bilaterally clinically involved nodes are predicted to have N2 disease and they may benefit from neoadjuvant chemotherapy. In patients with multiple, bulky or involved pelvic lymph nodes, multimodality approaches (including primary chemotherapy followed by surgery and node dissection) are preferred on the basis of a small number of retrospective studies (see Chemotherapy section) (Fig. 1).

\section{Clinically uninvolved lymph nodes}

In cases where lymph nodes are not clinically palpable or visibly enlarged radiographically, metastatic involvement will be present in $10 \%$ to $20 \%$ of lymph node dissections. ${ }^{31}$ Currently, the extent and timing of inguinal lymphadenectomy with or without sentinel biopsy remain controversial. We propose an algorithm for the management of the lymph nodes based on clinical involvement (Fig. 1).

At centres with the appropriate expertise, dynamic sentinel lymph node biopsy (which involves the injection of technetium-99m around the primary tumour), preoperative lymphoscintigraphy, and sentinel lymph node (SLN) identification using blue dye and a gamma ray detection probe to achieve physiologic rather than anatomic SLN identification may be considered. DSNB compares favourably to bilateral inguinal lymph node dissection by detecting similar rates of nodal metastases, but with less postoperative morbidity..$^{58}$ If the sentinel lymph node biopsy is positive, ipsilateral therapeutic, radical inguinal lymph node dissection should be performed. ${ }^{31,32,34}$

Early inguinal lymph node dissection in men with clinically negative nodes, but at high risk for nodal involvement, significantly improves cancer-specific survival and can be curative in $20 \%$ to $60 \%$ of histologically node-positive patients. ${ }^{34}$ However, even in node-negative men, inguinal lymph node dissection does not guarantee survival, with a 5 -year recurrence-free rate of $75 \%$ to $95 \%{ }^{38,39}$ While inguinal lymph node involvement is one of the strongest predictors in penile cancer, inguinal lymph node dissection must be weighed against the resulting morbidity, including infection, wound necrosis, and chronic leg edema. Therefore, the timing of inguinal lymph node dissection is an important consideration. Early inguinal lymph node dissection occurs within 6 weeks of primary tumour treatment in the absence of palpable lymph nodes. Delayed treatment is defined as dissection at the time of palpable node identification during follow-up. The potential benefits of delaying inguinal lymph node dissection were historically to allow a 6 -week course of antibiotic treatment, a regression of any inflammatory nodes, a decrease in the risk of wound infection, and possible avoidance of unnecessary surgery and its associated morbidity. However, recent evidence demonstrates improved survival outcomes ${ }^{59,60}$ without increased morbidity with early inguinal lymph node dissection when compared to delayed dissection. ${ }^{61,62}$

The need to balance the benefits of nodal dissection with the known morbidity has led to the development of models designed to predict the likelihood of nodal metas- 
tases. Individuals predicted as high risk of lymph node involvement can undergo early inguinal lymph node dissection, while those predicted to be at lower risk can opt for ongoing surveillance. Risk stratification can be based on the primary tumour histology. The presence of T2G2 or T2-3 G3 disease predicts lymph node involvement in up to $81 \%$ of cases. ${ }^{40}$ More recently, disease $\geq \mathrm{T} 1 \mathrm{G} 3$ has been considered high-risk disease. ${ }^{5}$ Predictions based on histologic criteria alone, however, are not highly reliable. Efforts to improve accuracy have led to the development of several nomograms. ${ }^{41-44}$ Three important points should be noted: (1) these tools remained largely unvalidated in prospective studies; ${ }^{41}(2)$ not all features can be determined for individuals undergoing penile conserving treatment; and (3) sensitivity, specificity, and false-negative rate are variable and are inferior to recent reports of high sensitivity (94\%) using dynamic sentinel node biopsy. ${ }^{45,46}$ Therefore when available, DSNB is preferred for risk stratification over nomograms. In line with these caveats, both the EAU and the National Comprehensive Cancer Network (NCCN) recommend tailoring a lymph node dissection based on clinical stage. Therefore, patients who are deemed compliant with no palpable lymphadenopathy and pTis, PTa and pTIG1 disease can undergo surveillance, while undergoing either modified bilateral lymphadenectomy or sentinel node dissection in the absence of palpable lymph nodes. Radical lymphadenectomy can be reserved for those patients with histologically proven inguinal lymph node involvement.

\section{Pelvic lymph nodes}

Involvement of the pelvic lymph nodes is not expected in the absence of inguinal lymph node involvement. If cancer is found in the inguinal nodes, ipsilateral pelvic (iliac) lymph node dissection should be considered in highly selected patients because about $30 \%$ of these nodes will harbor metastases. ${ }^{63}$ The likelihood of positive pelvic nodes is $23 \%$ for 2 positive inguinal nodes and $56 \%$ for either 3 involved nodes or extracapsular extension. ${ }^{5}$ Involvement of the most proximal (Cloquet's) node has a sensitivity of 30\% and specificity of $94 \%$ for pelvic lymph node metastases. Increased risk of pelvic node involvement is also associated with the lymph node ratio (number of positive nodes/total number removed) and increased p53 expression. ${ }^{64}$ It has been suggested that patients with a single involved inguinal lymph node, an uninvolved most proximal (Cloquet's) node, no evidence of extranodal extension, and no grade 3 tumour in an inguinal node do not benefit from pelvic lymph node dissection (PLND) ${ }^{20}$ For individuals with suspected pelvic node involvement, histologic confirmation should be sought because the presence of pelvic node metastases would indicate consideration of neoadjuvant therapy. PLND should occur by an open as opposed to a laparoscopic approach. ${ }^{32}$

\section{Advances in surgical techniques}

The goals of treatment are to maximize potential for cure, while also to minimize morbidity using penile preservation where possible. Appropriately selecting patients for management of nodal disease (in the hopes of limiting the potential morbid complications of lymph node dissection are also treatment goals. Treatment of penile cancer has a significant effect on psychosocial and sexual functioning - a patient's quality of life. ${ }^{49}$

Modified inguinal lymph node dissection has been proposed to minimize morbidity, while maintaining therapeutic benefit. ${ }^{65} \mathrm{~A}$ recent analysis assessed the impact of modified inguinal lymph node dissection on morbidity and survival. ${ }^{66}$ The authors concluded that the extent of lymph node dissection should be adapted to clinical stage, as this corresponds to metastatic spread. Low-risk patients with pTis, pTa, or pT1G1 disease, without palpable nodes and with good compliance, can undergo surveillance (Fig. 1). All other patients without palpable lymph nodes, including intermediate risk pT1G2 disease, should undergo modified bilateral lymphadenectomy in the absence of DSNB or histologic confirmation. The authors further recommended PLND in patients with more than 2 metastatic inguinal lymph nodes, although the therapeutic benefit of this approach is undemonstrated and limb morbidity increases significantly. In case of fixed inguinal lymph nodes or nodes $4 \mathrm{~cm}$ or greater, neoadjuvant chemotherapy or chemoradiotherapy is recommended, followed by node dissection.

Another alternative to radical inguinal lymph node dissection is video endoscopic inguinal lymphadenectomy, which can result in lower complication rates and shorter hospitalization than standard inguinal lymph node dissection. However, the data are not mature and longer followup is required to determine the false-negative and survival rates. The technique is not considered standard of care at this time (Box 4). ${ }^{67}$

\section{Box 4. Surgical management of the lymph nodes}

\section{Recommendations}

Inguinal node dissection should be performed in individuals with either histologically proven inguinal lymph node involvement or when individuals who are predicted to be high risk of inguinal lymph node involvement (Grade C).

Pelvic lymph node dissection should be considered in the presence of extranodal extension, Cloquet node involvement or involvement of two or more inguinal lymph nodes (Grade C).

\section{Radiation treatment of the primary tumour}

The recent EAU and NCCN guidelines support radiation therapy as a possible organ-preserving approach. ${ }^{5}$ It is most 
commonly used for T1 or T2 disease measuring $<4 \mathrm{~cm}^{68-70}$ as either external beam radiation or brachytherapy. Penile preservation after primary external beam radiotherapy was evaluated by McLean and colleagues. ${ }^{68}$ Patients stage T1-2 N0, received external beam radiation (35-60 Gy) to the primary tumour with or without radiation to the regional lymph nodes, leaving surgery for salvage upon relapse. Local control rate was $62 \%$ and the penile preservation rate was $66 \%$. Patients who underwent salvage penectomy remained disease-free. ${ }^{68}$ More recent data demonstrate an $88 \%$ 5-year survival rate with external beam radiotherapy, with inferior local control compared to penectomy. ${ }^{71}$ Superior local control is achieved using brachytherapy, with 5 -year penile preservation rates of $70 \%$ to $88 \%$ and 10 -year penile preservation rates of $67 \%$ to $72 \%$ (Level of evidence 2b). ${ }^{69,72-75}$ Cause-specific survival is similar to primary surgical approaches as salvage surgery is highly effective. ${ }^{69,75}$ Squamous carcinoma of the penis is a highly radiosensitive tumour, but radical doses in this site can result in complications including soft tissue necrosis $(12 \%)$ or meatal stenosis (9\%). ${ }^{69}$ Soft tissue necrosis often responds to conservative measures, including hyperbaric oxygen treatment, and only rarely requires amputation. Meatal stenosis can be prevented and/or effectively managed using a meatal dilator. Both these complications increase with increasing stage and tumour volume (Box 5).

\section{Box 5. Radiation therapy in the management of the primary tumour}

\section{Recommendations}

Brachytherapy or external beam radiation alone can be used as a penile preserving approach for tumours $<4 \mathrm{~cm}$ that are not extending beyond the glans (Grade B)

\section{Radiation treatment of the lymph nodes}

Prophylactic nodal radiation is not recommended for clinical N0 patients. It is not associated with a decreased risk of subsequent nodal metastasis, and its use in this setting may cause unnecessary radiation-associated morbidity and fibrotic changes that can complicate follow-up. ${ }^{5}$

Radiotherapy may be used in the neoadjuvant setting to downsize unresectable lymph nodes. An increased risk of nodal relapse $>15 \%$ is an indication for adjuvant radiotherapy for some tumour sites. For tumours with natural histories and lymph drainage similar to that of penile cancer (vulvar and anal cancer), lymph node irradiation is usually indicated, either as a neoadjuvant approach to surgery or as part of combined modality. ${ }^{76}$ Series evaluating the benefit of nodal radiation therapy are limited. One of the largest series evaluated 120 patients with nodal metastases. ${ }^{77}$ Of the 33 patients who received preoperative nodal radiation, only few had evidence of extranodal extension $(8 \%)$ or disease recurrence $(3 \%)$. These data compare favourably to historic data, suggesting 33\% extranodal extension and 19\% nodal recurrence. ${ }^{78}$ These data are used to support the use of radiation therapy to improve local control for lymph nodes of $4 \mathrm{~cm}$ or more without skin fixation. Similarly, combined modality treatment is the standard of care in squamous anal cancer through 4 key trials. ${ }^{79}$ An extrapolation from these studies supports the use of combined modality in penile cancer, particularly for individuals with inoperable inguinal lymph nodes. This approach is already in widespread use in tertiary referral centres while we await the results from a contemporary large cooperative international trial assessing neoadjuvant multimodality therapy for bulky or inoperable inguinal nodes. In the interim, by extrapolation of data from other squamous cell cancers, we agree with NCCN's recommendation of cisplatin or mitomycin, either alone or in combination with 5-FU, for concurrent use with radiotherapy.

In tumours of the penis, where locoregional control highly predicts prognosis, adjuvant inguinopelvic radiation may reduce the risk of recurrence in high-risk patients. If the status of the deep pelvic nodes is unknown, radiation to the pelvis may be included. If pelvic nodes are known to be histologically negative, radiotherapy can be limited to the inguinal region with a boost if necessary for known extracapsular disease (Box 6). ${ }^{73}$

\section{Box 6. Radiation therapy in the management of the lymph} nodes

\section{Recommendations}

Prophylactic RT is not recommended in N0 disease (Grade C).

Adjuvant (or neoadjuvant) RT of 45-70 Gy in cases of extensive metastases or extranodal spread improves locoregional control (Grade C). We are not yet able to clearly delineate which individuals will benefit from neoadjuvant vs. adjuvant treatment.

Consider concurrent treatment with radiation and chemotherapy (such as 5-FU) by extrapolation of squamous cell cancer studies in other tumour sites can be considered (Grade C).

\section{Using radiation in palliation}

Radiation therapy has the potential to reduce tumour size and provide local decompression. In patients with pelvic lymph node recurrence, radiation may palliate pain and lower extremity lymphedema. Published studies on this indication are rare. In cases of inguinal relapse, radiation therapy may reduce the risk of ulceration and bleeding. Chronic ulcers following radiation therapy should be considered recurrence until proven otherwise. ${ }^{80}$ In summary, palliative external beam radiation therapy can be considered for locally advanced metastatic disease. 


\section{Chemotherapy in the management of penile cancer}

\section{Neoadjuvant chemotherapy}

Neoadjuvant chemotherapy is defined as the use of systemic therapy (chemotherapy) before definitive local therapy. Neoadjuvant therapy aims to downstage or reduce the size or extent of the cancer to facilitate local treatment. In addition, neoadjuvant chemotherapy may eliminate micrometastatic disease. For example, in breast cancer treatment, pathological complete response has been correlated with improved long-term outcomes. ${ }^{81}$

For patients with palpable lymph nodes and especially with large, immobile inguinal nodal metastases, recent studies have shown promising results for neoadjuvant chemo- therapy followed by surgical node dissection. A small number of studies have been performed (Table 3). In a retrospective analysis, 12 out of 19 patients receiving neoadjuvant chemotherapy with different regimens (vincristine/ bleomycin/methotrexate, cisplatinum/bleomycin/methotrexate, cisplatinum/5-FU or cisplatinum/irinotecan) responded, and 8 of these patients achieved long-term survival after subsequent resection of the inguinal lymph node metastases. ${ }^{57}$ Bermejo and colleagues reported a complete response in 4 out of 5 patients receiving neoadjuvant treatment with paclitaxel/cisplatinum/ifosfamide, 3 of whom had a histologically demonstrated complete response. ${ }^{82}$ Cisplatinbased combinations showed similar benefit to bleomycin containing regimen in penile cancer, while avoiding the observed significant bleomycin-related toxicity. With these available alternatives, bleomycin containing regimens are

\begin{tabular}{|c|c|c|c|c|c|c|c|c|}
\hline Author & Design & Regimen & $\mathbf{n}$ & Clinical stage & N (\%) surgery & RR \% & PFS median & OS median \\
\hline $\begin{array}{l}\text { Bermejo } \\
\text { et al. }{ }^{82}\end{array}$ & Retrospective & $\begin{array}{l}\text { BMP } \\
\text { Bleomycin } 10 \mathrm{mg} / \mathrm{m}^{2} \text { day } 1-6 \\
\text { Methotrexate } 200 \mathrm{mg} \text { day } 1,15,21 \\
\text { Cisplatinum } 20 \mathrm{mg} / \mathrm{m}^{2} \text { day } 1-5 \\
\text { Every } 4 \text { weeks, } 2-9 \text { cycles } \\
\text { PCA } \\
\text { Paclitaxel } 80-200 \mathrm{mg} / \mathrm{m}^{2} \\
\text { Carboplatin (AUC 6) } \\
\text { Every } 3 \text { weeks } \times 4 \text { cycles } \\
\text { TIP } \\
\text { Paclitaxel } 175 \mathrm{mg} / \mathrm{m}^{2} \text { day } 1-5 \\
\text { Ifosfamide } 1.2 \mathrm{~g} / \mathrm{m}^{2} \text { day } 1-3 \\
\text { Cisplatin } 20 \mathrm{mg} / \mathrm{m}^{2} \text { day } 1-3 \\
\text { Every } 21 \text { days, } 4-5 \text { cycles }\end{array}$ & 10 & N1-3,or M1 & $10(100)$ & $\begin{array}{c}5 \\
(50)\end{array}$ & Not reported & 26 months \\
\hline $\begin{array}{l}\text { Leijte et } \\
\text { al. }{ }^{57}\end{array}$ & Retrospective & $\begin{array}{l}\text { Bleomycin } \\
\text { Bleomycin } 15 \mathrm{mg} \text { day } 1 \text { and } 3 \\
\text { Weekly } \times 12 \mathrm{max} \\
\text { BMP } \\
\text { Bleomycin } 15 \mathrm{mg} / \mathrm{m}^{2} \text { day } 1 \text { and } 2 \\
\text { Methotrexate } 30-50 \mathrm{mg} \text { day } 3 \\
\text { Cisplatinum } 20 \mathrm{mg} / \mathrm{m}^{2} \text { day } 2-5 \\
\text { Every } 3 \text { weeks, max } 5 \text { cycles } \\
\text { BVM } \\
\text { Vincristine } 1 \mathrm{mg} / \mathrm{m}^{2} \\
\text { Bleomycin } 15 \mathrm{mg} / \mathrm{m}^{2} \\
\text { Methotrexate } 30 \mathrm{mg} / \mathrm{m}^{2} \\
\text { Weekly } \times 12 \mathrm{weeks} \\
\text { CF } \\
\text { Cisplatinum } 100 \mathrm{mg} / \mathrm{m} 2 \\
5 \text { - fluorouracil } 1000 \mathrm{mg} / \mathrm{m} 2 \text { day } 1-5 \\
\text { Cl } \\
\text { Cisplatinum } 80 \mathrm{mg} / \mathrm{m}^{2} \text { on day } 1 \\
\text { Irinotecan } 60 \mathrm{mg} / \mathrm{m}^{2} \text { on day } 1 \text {, day } 8 \\
\text { every } 2 \text { weeks, } \mathrm{max} 8\end{array}$ & 20 & T4 or N3 & $9(45)$ & $\begin{array}{c}12 \\
(60)\end{array}$ & Not reported & $\begin{array}{c}32 \% \text { at } 5 \\
\text { years }\end{array}$ \\
\hline $\begin{array}{l}\text { Pagliaro } \\
\text { et al. }{ }^{83}\end{array}$ & Phase II & $\begin{array}{l}\text { ITP } \\
\text { Paclitaxel } 175 \mathrm{mg} / \mathrm{m}^{2} \text { day } 1 \\
\text { Ifosphamide } 1200 \mathrm{mg} / \mathrm{m}^{2} \text { day } 1-3 \\
\text { Cisplatinum } 25 \mathrm{mg} / \mathrm{m}^{2} \text { day } 1-3 \\
\text { Every } 3 \text { weeks } \times 4 \text { cycles }\end{array}$ & 30 & Any $\mathrm{T}, \mathrm{N} 2-3$ & $22(73.3)$ & $\begin{array}{c}15 \\
(50)\end{array}$ & 8.1 months & $\begin{array}{c}17.1 \\
\text { months }\end{array}$ \\
\hline
\end{tabular}


no longer used in standard practice.

The first prospective series of neoadjuvant chemotherapy was recently published. Similarly, promising data with the same neoadjuvant regimen were reported by Pagliaro and colleagues, with 15 of 30 patients achieving a response and 9 patients long-term survival. ${ }^{83}$ The treatment was welltolerated; the most common significant toxicity was grade 3 infection. Pizzocaro and colleagues used a neoadjuvant regimen of paclitaxel/ cisplatinum and 5-FU and reported a response in all 3 patients treated. ${ }^{84}$

For patients with penile carcinoma and fixed inguinal lymph node metastases or mobile nodes of $4 \mathrm{~cm}$ or greater, neoadjuvant chemotherapy followed by lymph node dissection should be given to patients whose disease responds to treatment. There is also likely to be a benefit in patients with

\section{Box 7. Neoadjuvant chemotherapy}

\section{Recommendations}

Neoadjuvant chemotherapy can be considered for inguinal lymph nodes measuring $4 \mathrm{~cm}$ or more (fixed or mobile) (Grade C).

Neoadjuvant regimen should contain cisplatinum. Bleomycincontaining regimen should not be used. Neoadjuvant regimen have not been evaluated in randomized studies to allow a strong recommendation of one regimen over another. (Grade $\mathrm{C}$ ). An acceptable example is four cycles of paclitaxel $175 \mathrm{mg} / \mathrm{m}^{2}$ on day 1 , ifosfamide $1200 \mathrm{mg} / \mathrm{m}^{2}$ on d 1 to 3 and cisplatinum $25 \mathrm{mg} / \mathrm{m}^{2}$ on day 1 to 3 .

Neoadjuvant regimen or chemoradiation should be considered first line treatment for N2-3 disease. Surgery should offered to those with evidence of response to neoadjuvant chemotherapy (Grade C).

N2 disease, but data are lacking. Again, while the principle seems to be established, it is unclear which, if any, of the possible chemotherapy regimens is most suitable, how many cycles should be given, and what the time interval should be between chemotherapy and surgery. Data about the relative rate of complications in patients undergoing inguinal lymphadenectomy with or without neoadjuvant chemotherapy are also lacking (Box 7).

\section{Adjuvant chemotherapy}

Adjuvant chemotherapy is defined as the use of systemic therapy after definitive local therapy to eradicate micrometastases and reduce the risk of recurrence. Adjuvant chemotherapy in completely resected penile cancer with adverse features has not been rigorously tested (Table 4). Based on a contemporary series of patients treated with surgery alone, the 2-year disease-free survival rate in patients with bilateral inguinal metastases is $53.1 \%$, while 3 -year survival rates are $21.2 \%{ }^{85}$ Thus, surgery alone is often inadequate to prevent disease recurrence. The EAU currently recommends, however, that adjuvant chemotherapy should be

\begin{tabular}{|c|c|c|c|c|}
\hline Author & Design & Regimen & $\mathbf{n}$ & $\begin{array}{l}\text { Overall } \\
\text { survival } \\
\text { median }\end{array}$ \\
\hline $\begin{array}{l}\text { Pizzocaro } \\
\text { and } \\
\text { Piva }^{104}\end{array}$ & Retrospective & $\begin{array}{l}\text { VBM } \\
\text { Vincristine } 1 \mathrm{mg} / \mathrm{m}^{2} \\
\text { Bleomycin } 15 \mathrm{mg} / \mathrm{m}^{2} \\
\text { Methotrexate } 30 \\
\mathrm{mg} / \mathrm{m}^{2} \\
\text { Weekly } \times 12 \text { weeks }\end{array}$ & 12 & $\begin{array}{c}\text { Not } \\
\text { reported }\end{array}$ \\
\hline $\begin{array}{l}\text { Pizzocaro } \\
\text { et al. }{ }^{86}\end{array}$ & Retrospective & $\begin{array}{l}\text { VBM } \\
\text { Vincristine } 1 \mathrm{mg} / \mathrm{m}^{2} \\
\text { Bleomycin } 15 \mathrm{mg} / \mathrm{m}^{2} \\
\text { Methotrexate } 30 \\
\mathrm{mg} / \mathrm{m}^{2} \\
\text { Weekly } \times 12 \text { weeks }\end{array}$ & 25 & $\begin{array}{c}82 \% \text { at } 5 \\
\text { years }\end{array}$ \\
\hline
\end{tabular}

offered to patients with N2 (palpable, mobile and multiple lymph nodes, uni- or bilateral) disease, while the NCCN recommends adjuvant chemotherapy for lymph node size $4 \mathrm{~cm}$ or more. This is on the basis of a retrospective study by Pizzocaro and colleagues. In this small study, 12 patients with surgically resected inguinal lymph node metastases who had adjuvant vincristine, methotrexate, bleomycin chemotherapy were compared with historic controls who did not receive chemotherapy. The 5-year survival rate was $82 \%$ with adjuvant chemotherapy compared with $37 \%$ in the historic control group. ${ }^{86}$ In addition, none of the stage N1 patients (palpable, mobile unilateral lymph node metastases) who received chemotherapy developed progressive disease. Pizzocaro and colleagues also evaluated patients treated with either 12 weeks of vinblastine-bleomycin-methotrexate (VBM) or cisplatin-5-FU in the adjuvant setting. ${ }^{84}$ Adjuvant VBM was associated with an $84 \%$ disease-free survival compared to $39 \%$ in historic controls. However, treatment with bleomycin in these studies was associated with significant

\section{Box 8. Adjuvant chemotherapy}

\section{Recommendations}

Patients with N1 disease do not require adjuvant chemotherapy (Grade C).

Adjuvant chemotherapy can be considered in individuals with poor prognostic features including N2-3, lymph node $4 \mathrm{~cm}$ or more, extranodal extension) following radical lymph node dissection. Although evidence is sparse, there is potential benefit to considering chemotherapy given the poor outcomes associated with surgery alone in this population. Regimen should be cisplatin based, may contain a taxane and blemycin should be avoided. Little data is available to guide dose and cycles and we suggest extrapolation of neoadjuvant regimen (Grade C).

Examples of acceptable adjuvant chemotherapy regimen

TIP: paclitaxel $175 \mathrm{mg} / \mathrm{m}^{2}$ on day 1 , ifosfamide $1200 \mathrm{mg} / \mathrm{m}^{2}$ on d1 to 3 and cisplatinum $25 \mathrm{mg} / \mathrm{m}^{2}$ on day 1 every 3 weeks for 4 cycles

Cis-5FU: cisplatinum $100 \mathrm{mg} / \mathrm{m}^{2}$ on day $1,5 \mathrm{FU} 1000 \mathrm{mg} / \mathrm{m}^{2} /$ day by continuous infusion on day 1-5 every 3 to 4 weeks for 2 cycles 
treatment related morbidity and mortality. Treatment with cisplatin-5-FU was notably less toxic and further improved outcomes in patients with pN2-3 disease or extranodal extension. There is also increasing interest in the incorporation of taxanes into the adjuvant regimens and further study in this area is needed. ${ }^{87}$

There is a paucity of data to guide recommendations for adjuvant chemotherapy in penile cancer (Box 8). We agree with the NCCN guidelines which suggest, on the basis of extrapolation of neoadjuvant data, the use of paclitaxel/ ifosphamide/cisplatin for 4 cycles (Table 4 ).

\section{Unresectable and metastatic disease}

Chemotherapy has a role in the management of penile cancer for patients with advanced disease (T4), lymph node metastases, unresectable disease and in the palliation of distant disease. Most of the data evaluating chemotherapy for penile cancer have been generated in the neoadjuvant setting in attempt to downstage unresectable, bulky regional disease (stage III and IV).

Bulky unresectable disease occurs in up to $13.4 \%$ of cases. Leijte and colleagues evaluated 5 separate regimens, including bleomycin-methotrexate-cisplatin (BMP) and cisplatin-5-FU (adopted from squamous cell carcinomas of the head and neck). ${ }^{57}$ Response rates were $33 \%$ to $63 \%$; however, bleomycin-containing regimens were associated with increased toxicity and a high rate of treatment-related deaths. Importantly, the authors found that patients achieving objective response to chemotherapy benefitted the most from surgery with a chance for cure. More recently, the activity of taxanes with a cisplatin-containing regimen has been evaluated with promising results. The addition of a taxane to cisplatin-5-FU (TPF) yielded improved pathologic responses and survival in a small series. ${ }^{84}$ The use of neoadjuvant paclitaxel-cisplatin-ifosphomide (TIP) resulted in several pT0 events in a retrospective analysis of 10 patients with lymphadenopathy greater than $4 \mathrm{~cm} .{ }^{82}$ This regimen has been evaluated further by Pagliaro and colleagues. ${ }^{83}$ It is the largest trial of regionally advanced patients (stage N2 or N3) treated with neoadjuvant chemotherapy, including a total of 30 patients. TIP resulted in a $10 \%$ pathologic complete response $(\mathrm{pCR})$ rate and an objective response rate of $50 \%$. This represents a significant improvement over historic controls and suggests a possibility for cure in individuals initially deemed unresectable (Level of evidence 2b). TIP was also less toxic than older regimens, with no treatment-related deaths and the most severe toxicity being febrile neutropenia. Survival advantage correlated with treatment response and absence of extranodal extension or skin involvement. Caveats are the exclusion of patients with visceral metastases, the difficulty in evaluating overall survival data in a nonrandomized phase II study, and, despite being the largest to date, is a study with a small study sample size. In addition, in the setting of bulky or inoperable lymph nodes, multimodality therapy with chemoradiation is widespread practice at large tertiary centres. The preferred regimen for radiosensitizing includes cisplatin alone or in combination with 5-FU or mitomycin $\mathrm{C}$ in combination with 5-FU or capecitabine. ${ }^{79}$ This practice is based on data extrapolated from squamous cell cancers of the anus and vulva, pending a confirmatory trial specific to squamous penile cancer.

Metastatic disease is associated with a survival of 2 to 12 months. Penile cancer progresses from the inguinal and pelvic lymph nodes to hematogenous spread. The incidence of distant disease at the time of diagnosis is between $1.9 \%$ and $7.0 \%{ }^{84}$ The disease often spreads to the lung, bone, and soft tissue. Chemotherapy can be considered in these patients for potential palliative benefits. Combination chemotherapy using cisplatin-gemcitabine and cisplatin-irinotecan $^{88}$ has demonstrated encouraging activity and tolerability in patients with metastatic disease. Similar efficacy was observed with bleomycin-containing regimen, but treatmentrelated mortality was higher. A Southwest Oncology Group study of cisplatin-methotrexate-bleomycin demonstrated a $32.5 \%$ response rate (Level of evidence $2 \mathrm{~b}$ ). ${ }^{89}$ The European Organization for Research and Treatment of Cancer (EORTC) study evaluating cisplatin-irinotecan reported a $31 \%$ response rate, although in a heterogenous population that included locally advanced disease (Level of evidence 2b). ${ }^{90}$ In their recent review of treatment for unresectable penile cancer, Pettaway and colleagues recommended that a cis-

\begin{tabular}{|c|c|c|c|c|c|c|}
\hline Author & Design & Regimen & $\mathbf{n}$ & RR \% & PFS median & OS median \\
\hline Di Lorenzo et al. ${ }^{105}$ & First-line retrospective & $\begin{array}{l}\text { Cisplatinum } 75 \mathrm{mg} / \mathrm{m}^{2} \text { on day } 1 \\
\text { 5-fluorouracil } 900 \mathrm{mg} / \mathrm{m}^{2} \times 4 \text { days } \\
\text { Every } 21 \text { days } \times 4 \mathrm{cycles}\end{array}$ & 25 & $8(32)$ & 5 months & 8 months \\
\hline Di Lorenzo et al..$^{92}$ & Second-line phase II & Paclitaxel $175 \mathrm{mg} / \mathrm{m}^{2}$ every 3 weeks & 25 & $5(20)$ & 2.7 months & 5.7 months \\
\hline Gagliano et al. ${ }^{106}$ & First-line phase II & $\begin{array}{l}\text { Cisplatin } 50 \mathrm{mg} / \mathrm{m}^{2} \text { on day } 1 \text { and day } 8 \\
\text { Every } 21 \text { days }\end{array}$ & 26 & $4(15.4)$ & NR & 4.7 months \\
\hline Haas et al. ${ }^{89}$ & First-line phase II & $\begin{array}{l}\text { Bleomycin } 10 \mathrm{mg} / \mathrm{m}^{2} \text { day } 2-6 \\
\text { Methotrexate } 200 \mathrm{mg} / \mathrm{m}^{2} \text { day } 1 \text { and } 15 \\
\text { Cisplatinum } 20 \mathrm{mg} / \mathrm{m}^{2} \text { day } 2-6\end{array}$ & 40 & $13(32.5)$ & NR & 7 months \\
\hline
\end{tabular}




\section{Box 9. Chemotherapy for metastatic disease}

\section{Recommendations}

Metastatic disease should be treated with cisplatin containing regimens. Bleomycin containing regimens should be avoided (Grade C).

platin-containing regimen be considered in stage 4 penile cancer and the use of bleomycin-containing regimen was discouraged. ${ }^{91}$ The addition of a taxane may be reasonable given the observed objective response rates when used in the neoadjuvant setting for bulky unresectable disease (Box 9).

Limited data are available to evaluate the activity of second-line chemotherapy in pre-treated patient populations. A recent phase II trial of single agent paclitaxel for pre-treated metastatic penile carcinoma showed a response rate of $20 \%$ (Level of evidence $2 \mathrm{~b}$ ). ${ }^{92}$

\section{Chemotherapy for locally recurrent disease}

Local recurrence is more common after penile preservation than after amputation. However, local control can be subsequently achieved in $94 \%$ of cases with no significant association between local recurrence and either nodal metastasis or cancer-specific survival (Level of evidence 2b). ${ }^{93}$ In particular, surgical salvage after penile preserving treatment with brachytherapy is highly successful, such that local failures do not cause any decrease in cause-specific survival between 5 and 10 years. ${ }^{53,54}$ Local recurrences, however,

\section{Box 10. Treatment of locally recurrent disease}

\section{Recommendations}

A repeated penile-preserving strategy can be used for local recurrence in the absence of prior radiation or corpora cavernosal involvement (Grade C).

Debulking chemotherapy should be considered for recurrent lymph nodes metastases (Grade C).

can occur very late, even up to 10 years after treatment; for this reason, prolonged follow-up is essential. The same phenomenon is reported after penile-preserving laser ablation of superficial disease.
In the case of nodal recurrence, neoadjuvant chemotherapy should be considered (Level of evidence 2b).,57 Recent data, however, suggest that response to salvage treatment in patients previously treated with TIP was low (Box 10). ${ }^{94}$

\section{Biomarkers}

There are no validated markers in penile cancer. p53, Ki67 and E-cadherin have been correlated to lymph node metastasis, but have no role in clinical decision-making. ${ }^{95}$ Although the disease is rare, knowledge in part may be garnered by extrapolation from the squamous cell carcinoma experience of other tumour sites, such as head and neck and anal carcinoma in which estimated glomerular filtration rate (EGFR) status and use of anti-EGFR therapies have improved outcomes and predicted response to radiotherapy. ${ }^{96} \mathrm{~A}$ recent retrospective study of erlotinib alone, cetuximab, or cetuximab in combination with cisplatin had an overall survival of 2.8 to 48 months, with a median time to disease progression between 0.37 and more than $>37$ months. ${ }^{97}$ Recent data support the potential for anti-EGFR therapy in penile cancer. ${ }^{98}$ Neoadjuvant chemotherapy in combination with EGFR inhibitors followed by consolidative surgical resection is of significant clinical interest; we await results of planned phase II prospective trials.

\section{Psychosocial considerations}

Residual penile shaft lengths measuring $4 \mathrm{~cm}$ or more may preserve erectile and ejaculatory function, ${ }^{99}$ but still result in significant reduction of sexual frequency and satisfaction. Although amputation can increase cure rates, the therapeutic benefits must be weighed against the psychosocial morbidity. In a systemic review of quality of life in patients affected by penile cancer, $40 \%$ of patients experienced negative effects on well-being; psychiatric symptoms were identified in $50 \%$ of patients. ${ }^{100}$ There are no standardized intervention tools to date. Knowledge and awareness of the potential impact on psychosocial well-being and the opportunity to intervene may improve quality of life in patients affected by penile cancer.

Table 6. Guidelines for follow-up in penile cancer (adapted from the EAU and NCCN guidelines)

\begin{tabular}{|c|c|c|c|c|}
\hline Treatment & Follow-up year $1+2$ & Follow-up year 3-5 & Follow-up year $>5$ & Workup \\
\hline Penile preserving & 3 months & 6 months & Annually & Regular physician or self-examination \\
\hline Penectomy & 6 months & 12 months & & Regular physician or self-examination \\
\hline Surveillance & 3 months & 6 months & & $\begin{array}{l}\text { Regular physician or self-examination } \\
\text { Ultrasound and FNAB of abnormal node }\end{array}$ \\
\hline pNO & 6 months & 12 months & & $\begin{array}{l}\text { Regular physician or self-examination } \\
\text { Ultrasound and FNAB of abnormal node }\end{array}$ \\
\hline pN1+ & 3 months & 6 months & & $\begin{array}{l}\text { Regular physician or self-examination } \\
\text { Ultrasound and FNAB of abnormal node }\end{array}$ \\
\hline
\end{tabular}




\section{Post-treatment surveillance}

The primary goal of follow-up is to detect local and/or regional recurrences that are potentially curable (Table 6). The goals of treatment in the case of distant metastases are palliative. Surveillance scheduling should be based on the initial treatment. One large series showed that $92.2 \%$ of all recurrences occurred within the first 5 years, ${ }^{101}$ but may occur more than a decade later. ${ }^{53,102}$ Early detection of recurrence is particularly important with the increasing use of penile-sparing approaches. ${ }^{103}$ Regular surveillance also allows us to assess any treatment-related complications ${ }^{5}$ and to evaluate our ongoing treatment policy. Patient self-examination as an alternative to examination by a physician may be appropriate for reliable patients. In cases where care is shared with a general practitioner or other healthcare provider, a care plan noting frequency of follow-up, signs/symptoms of concern and reason for re-referral with specific information should be provided. All follow-up should be to a minimum of 5 years, and should be continued indefinitely after penile-sparing approaches.

\section{Summary}

Penile cancer is an uncommon, but potentially curable, disease. Most published studies are small, single institution case series and a limited number of non-randomized clinical trials. The rarity of the disease has been prohibitive to large cooperative randomized controlled trials and the available trials and series are too heterogeneous to be combined in a meta-analysis.

Management should occur at an experienced centre. Primary prevention includes avoiding HPV and HIV risk factors, smoking cessation, patient awareness and self-examination. Accurate staging is paramount. PET scans should be considered to improve staging workup. Penile-sparing approaches, including penile-sparing surgery, brachytherapy, or radiotherapy should be considered where possible.

The management of the lymph nodes is important and controversial. Goals include maximizing the chance for cure, while minimizing unnecessary lymphadenectomyassociated morbidity. Important concepts include: (i) the use of neoadjuvant chemoradiotherapy in individuals with fixed or relapsed lymph nodes to improve resectability and outcome; (ii) the use of taxane- and cisplatin-containing chemotherapeutic regimen with TIP as an emerging preferred regimen; (iii) the use of chemotherapy in patients with $\mathrm{pN} 2$ or $\mathrm{pN} 3$ disease following lymph node dissection; and (iv) the similarities between penile cancers and squamous cancers of the head and neck may allow further exploration of EGFR targeted therapies. Patients who are unresponsive to neoadjuvant chemoradiotherapy may undergo palliative surgery. The psychosocial impact of penile cancer should not be forgotten; patients may benefit from psychosocial support.
Future directions include identification of predictors of response to chemotherapy, including HPV status, as seen in head and neck cancers. Ongoing efforts towards accurate prediction of nodal involvement in patients with clinically negative nodes allow for better selection of those patients warranting early surgical resection, while sparing patients at lower risk of nodal involvement the morbidity associated with nodal dissection. The extension of TIP into the adjuvant setting may also be beneficial. In addition, chemotherapy use earlier in disease management may improve penilepreserving strategies and long-term outcomes.

Experience in the field is growing and increasing published reports are becoming available. Collaborative multi-institutional studies are encouraged. The generation of a Canadian registry may allow for increased sample size evaluation and impact analysis of our proposed nationwide guidelines on improving care of patients affected by penile cancer.

Competing interests: Dr. Richter, Dr. Sridhar, Dr. Zalewki, Dr. Crook, Dr. Moretto, Dr. Venner, Dr. Eisen, Dr. Joshua, Dr. Heng, Dr. Soulieres and Dr. Blais all declare no competing financial or personal interests. Dr. Ruether has been a speaker and an Advisory Board consultant for Pfizer, Novartis, Bayer Johnson \& Johnson and Astellas and has received honoraria for these roles. He has also be a site principal investigator in clinical trials for Novartis, Pfizer, Astellas, Johnson \& Johnson and the Cooperative Group. Dr. Wood has been a member of the Advisory Board for Pfizer, Astellas and Janssen, with no personal financial compensation. She has also participated in clinical trials for GlaxoSmithKline, BMS, Astellas and Novartis, but has also not received personal financial compensation. Dr. Gingerich has participated in an Advisory Board for Amgen. He is also participating in a clinical trial for Oncogenex and Janssen Biotech. Dr. Emmenegger has been a member of the scientific Advisory Board for Amgen, Astellas, Bayer, Janssen, Novartis and Sanofi; he has received honoraria for these roles. He is also local principal investigator of trials with Oncogenex, Astellas and Teva. Dr. Mukherjee has received a travel grant from Amgen, has received honoraria for his participation in Advisory Boards for Janssen, Astellas, Sanofi and Pfizer. He has also been a local principal investigator for a clinical trial for Astellas, Janssen and Oncogenex. Dr. Czaykowski is a local investigator for multiple companies, yet has not received direct financial or other renumeration. Dr. Rendon has received honoraria from Amgen, Astellas, Ferring and Janssen for participation in Advisory Boards and their Speaker's bureau. Dr. Fleshner is a member of the Advisory Board for Amgen, Janssen, Astellas, and Eli Lily and has received honoraria for his roles. He has also participated in clinical trials for Amgen, Janssen, Medivation, the Ontario Institute for Cancer Research, and Prostate Cancer Canada. Dr. Canil has participated in Advisory Boards for Janssen, Pfizer, Astellas and Amgen. She has received speaking fees for Janseen and Astellas and travel grants from Novartis and Janssen. She has been an investigator in clinical trials for Pfizer, Janssen, Astellas and Sanofi Oncology.

This paper has been peer-reviewed.

\section{References}

1. Barnholtz-Sloan JS, Maldonado JL, Pow-Sang J, et al. Incidence trends in primary malignant penile cancer. Urol Oncol 2007;25:361-7. http://dx.doi.org/10.1016/i.urolonc.2006.08.029

2. Canadian Cancer Society's Steering Committee on Cancer Statistics. Canadian Cancer Statistics 2011. Toronto, ON: Canadian Cancer Society; 2011.

3. American Cancer Society. Cancer Facts and Figures 2011. Atlanta, Ga: American Cancer Society; 2011.

4. Pompao ACL, Heyns C, Abrams P, eds. International Consultation on Penile Cancer, 2009.

5. Pizzocaro G, Algaba F, Horenblas S, et al. EAU penile cancer guidelines 2009. Eur Urol 2010;57:1002-12. http://dx.doi.org/10.1016/i.eururo.2010.01.039 
6. Johnson TV, Hsiao W, Delman KA, et al. Extensive inguinal lymphadenectomy improves overall 5-year survival in penile cancer patients: results from the Surveillance, Epidemiology, and End Results program. Cancer 2010;116:2960-6. http://dx.doi.org/10.1002/cncr.25091

7. Oxford Centre for Evidence-based Medicine Levels of Evidence (May 2009). Produced by Bob Phillips, Chris Ball, Dave Sackett, Doug Badenoch, Sharon Straus, Brian Haynes, Martin Dawes since November 1998. Updated by Jeremy Howick March 2009. httr://www.cebm.net/index.aspx?0=1025. Accessed November 7, 2013.

8. National Comprehensive Cancer Network. NCCN Guidelines (Version 1.2013). http://www.nccn.org/ professionals/physician_gls/f_guidelines.asp. Accessed November 7, 2013.

9. Brouwers M, Kho ME, Browman, et al. for the AGREE Next Steps Consortium. AGREE II: Advancing guideline development, reporting and evaluation in healthcare. CMAJ 2010;182:e839-e842. http:// dx.doi.org/10.1503/cmai.090449

10. Maden C, Sherman KJ, Beckmann AM, et al. History of circumcision, medical conditions, and sexual activity and risk of penile cancer. J Natl Cancer Inst 1993;85:19-24. http://dx.doi.org/10.1093/inci/85.1.19

11. Schoen EJ. The relationship between circumcision and cancer of the penis. CA Cancer J Clin 1991;41:306-9. http://dx.doi.org/10.3322/caniclin.41.5.306

12. Albero $G$, Castellsagué $X$, Giuliano AR, et al. Male Circumcision and Genital Human Papillomavirus: $A$ Systematic Review and Meta-Analysis. Sex Transm Dis 2012;39:104-13. http://dx.doi.org/10.1097/ 0LQ.0b013e3182387abd

13. Saibishkumar EP, Crook J, Sweet J. Neonatal circumcision and invasive squamous cell carcinoma of the penis: a report of 3 cases and a review of the literature. Can Urol Assoc J 2008;2:39-42.

14. Morris BJ, Wodak AD, Mindel A, et al. Infant male circumcision: An evidence-based policy statement. Open Journal of Preventive Medicine 2012;2:79-92.

15. Miralles-Guri C, Bruni L, Cubilla AL, et al. Human papillomavius prevalence and type distribution in penile carcinoma. J Clin Pathol 2008;62:870-8. http://dx.doi.org/10.1136/icp.2008.063149

16. Grussendorf-Conen El, Meinhof W, de Villiers EM, et al. Occurrence of HPV genomes in penile smears of healthy men. Arch Dermatol Res 1987;279:S73. http://dx.doi.org/10.1007/BF00585925

17. Giuliano AR, Palefsky JM, Goldstone $S$, et al. Efficacy of Quadrivalent HPV Vaccine against HPV Infection and Disease in Males. N Engl J Med 2011;364:401-11. http://dx.doi.org/10.1056/NEJMoa0909537

18. Frisch M, Biggar RJ, Engels EA, et al.; AIDS-Cancer Match Registry Study Group. Association of cancer with AIDS-related immunosuppression in adults. JAMA 2001;285:1736-45. http://dx.doi.org/10.1001/ jama.285.13.1736

19. Kayes 0 , Minhas $S$, Allen $C$, et al. The role of MRI in the local staging of penile cancer. Eur Urol 2007;51:1313-9. http://dx.doi.org/10.1016/i.eururo.2006.11.014

20. Horenblas $S$, Kröger $R$, Gallee MP, et al. Ultrasound in squamous cell carcinoma of the penis; a useful addition to clinical staging? A comparison of ultrasound with histopathology. Urology 1994;43:702-7. http://dx.doi.org/10.1016/0090-4295(94)90189-9

21. Lont AP, Besnard AP, Gallee MP, et al. A comparison of physical examination and imaging in determining the extent of primary penile carcinoma. BJU Int 2003;91:493-5. http://dx.doi.org/10.1046/j.1464410X.2003.04119.x

22. Lucia MS, Miller GJ. Histopathology of malignant lesions of the penis. Urol Clin North Am 1992;19:227.

23. Cabilla AL. The role of pathologic prognostic factors in squamous cell carcinoma of the penis. World I Urol 2008;27:169-77. http://dx.doi.org/10.1007/s00345-008-0315-7

24. Lopes A, Hidalgo GS, Kowalski LP, et al. Prognostic factors in carcinoma of the penis: multivariate analysis of 145 patients treated with amputation and lymphadenectomy. J Urol 1996;156:1637-42.

25. Slaton JW, Morgenstern N, Levy DA, et al. Tumor stage, vascular invasion and the percentage of poorly differentiated cancer: independent prognosticators for inguinal lymph node metastasis in penile squamous cancer. J Urol 2001;165:1138-42. http://dx.doi.org/10.1016/S0022-5347(05)66450-6

26. Villavicencio $H$, Rubio-Briones J, Regalado R, et al. Grade, local stage and growth pattern as prognostic factors in carcinoma of the penis. Eur Urol 1997;32:442-7.

27. Guimarães $G C$, Lopes $A$, Campos $R S$, et al. Front pattern of invasion in squamous cell carcinoma of the penis: new prognostic factor for predicting risk of lymph node metastases. Urology 2006;68:148-53.

28. Emerson RE, Ulbright TM, Eble JN, et al. Predicting cancer progression in patients with penile squamous cell carcinoma: the importance of depth of invasion and vascular invasion. Mod Pathol 2001;14:963-8. http://dx.doi.org/10.1038/modpathol.3880419

29. American Joint Committee on Cancer, "Penis," in American Joint Committee on Cancer; S. B. Edge, D. R. Byrd, C. C. Compton, eds. Springer, New York, NY, USA, 7th edition; 2010:447.

30. Leijte JAP, Valdes Olmos RA, Neiweg OE, et al. Anatomical mapping of lymphatic drainage in penile carcinoma with SPECT-CT implications for the extent of inguinal lymph node dissection. Eur Urol 2008;54:885992. http://dx.doi.org/10.1016/i.eururo.2008.04.094

31. Hughes $B$, Leijte J, Shabbir $M$, et al. Non-invasive and minimally invasive staging of regional lymph nodes in penile cancer. World J Urol 2009;27:197-203. http://dx.doi.org/10.1007/s00345-008-0288-6

32. Heyns CF, Fleshner N, Sangar V, et al. Management of the lymph nodes in penile cancer. Urology 2010;76:S43-57
33. Grafland NM, Teertstra HJ, Besnard AP, et al. Identification of high risk pathological node positive penile carcinoma: value of preoperative computerized tomography imaging. J Urol 2011;185:881-7. http:// dx.doi.org/10.1016/i.juro.2010.10.058

34. Tabatabaei S, Harisinghani M, McDougal WS. Regional lymph node staging using lymphotropic nanoparticle enhanced MRI with ferumoxtran-10 in patients with penile cancer. J Urol 2005;174:923-7. http:// dx.doi.org/10.1097/01.ju.0000170234.14519.19

35. Schlenker $B, S$ cher $B$, Tiling $R$, et al. Detection of inguinal lymph node involvement in penile squamous cell carcinoma by 18F-fluorodeoxyglucose PET/CT: A prospective single-center study. Urol Oncol 2012;30:55-9. http://dx.doi.org/10.1016/i.urolonc.2009.10.012

36. Mueller-Lisse UG, Scher B, Scherr MK, et al. Functional imaging in penile cancer. Pet/computed tomography, MRI and sentinel lymph node biopsy. Curr Opin Urol 2008;18:2105-10. http://dx.doi. org/10.1097/MOU.0b013e3282f151fd

37. Saisorn I, Lawrentschuk $N$, Leewansangtong $S$, et al. Fine-needle aspiration cytology predicts inguinal lymph node metastasis without antibiotic pretreatment in penile carcinoma. BJU Int 2006;97:1225-8. http://dx.doi.org/10.1111/j.1464-410X.2006.06159.x

38. Kroon BK, Horenblas $\mathrm{S}$, Deurloo $\mathrm{EE}$, et al. Ultrasonography guided fine-needle aspiration cytology before sentinel node biopsy in patients with penile carcinoma. BJU Int 2005;95:517-21. http://dx.doi. org/10.1111/i.1464-410X.2005.05330.x

39. Graafland NM, Olmos RA, Meinhardt W, et al. Nodal Staging in Penile Carcinoma by Dynamic Sentinel Node Biopsy After Previous Therapeutic Primary Tumour Resection. Eur Urol 2010;58:e51-2.

40. Heyns CF, Fleshner N, Sangar V, et al. Management of the lymph nodes in penile cancer. Urology 2010;76:S43-57. http://dx.doi.org/10.1016/j.urology.2010.03.001

41. Graafland NM, Leijte JA, Valde's Olmos RA, et al. Repeat dynamic sentinel node biopsy in patients with locally recurrent penile carcinoma. Eur Urol Suppl 2009;8:368, abstract 991. http://dx.doi. org/10.1016/S1569-9056(09)60976-3

42. Horenblas $S$. Lymphadenectomy for squamous cell carcinoma of the penis Part 1: Diagnosis of lymph node metastasis. BJU Int 2001;88:467-72. http://dx.doi.org/10.1046/i.1464-410X.2001.00380.x

43. Hughes $B$, Leiite J, Shabbir $M$, et al. Non-invasive and minimally invasive staging of the regional lymph nodes in penile cancer. World J Urol 2009;27:197-203. http://dx.doi.org/10.1007/s00345-008-0288-6

44. Davis JW, Schellhammer PF, Schlossberg SM. Conservative surgical therapy for penile and urethral carcinoma. Urology 1999; 53: 386-392. http://dx.doi.org/10.1016/50090-4295(98)00483-X

45. van Bezooijen BP, Horenblas $S$, Meinhardt W, et al. Laser therapy for carcinoma in situ of the penis. J Urol 2001; 166 (5): 1670-1671. http://dx.doi.org/10.1016/S0022-5347(05)65650-9

46. Paoly J, Ternesten Bratel A, Lowhagen GB, et al. Penile intragenital neoplasia : results of photodynamic therapy. Acta Derm Venereal 2006;86:418-21.

47. Mohs FE, Snow SN, Messing EM, et al. Microscopically controlled surgery in the treatment of carcinoma of the penis. J Urol 1985; 133:961-6.

48. Goette DK, Carson TE. Erythroplasia of Queyrat: treatment with topical 5-fluorouracil. Cancer 1976;38:1498.

49. D'Ancona CA, Botega NJ, De Moraes C, et al. Quality of life after partial penectomy for penile carcinoma. Urology 1997;50:593. http://dx.doi.org/10.1016/S0090-4295(97)00309-9

50. Smith Y, Hadway P, Ahmed S, et al. Penile-preserving surgery for male distal urethral carcinoma. BJU Int 2007;100:82-7. http://dx.doi.org/10.1111/i.1464-410X.2007.06901.x

51. Bandieramonte G, Colecchia M, Mariani L, et al. Peniscopically controlled CO2 laser excision for conservative treatment of in situ and Tl penile carcinoma: report on 224 patients. Eur Urol 2008;54:875-82. http:// dx.doi.org/10.1016/i.eururo.2008.01.019

52. Azrif $M$, Logue JP, Swindell R, et al. External-beam radiotherapy in T1-2 NO penile carcinoma. Clin Oncol (R Coll Radiol) 2006;18:320-5. http://dx.doi.org/10.1016/i.clon.2006.01.004

53. de Crevoisier R, Slimane K, Sanfilippo N, et al. Long-term results of brachytherapy for carcinoma of the penis confined to the glans (N- or NX). Int J Radiat Oncol Biol Phys 2009;74:1150-6. http://dx.doi. org/10.1016/i.i.irobp.2008.09.054

54. Crook JM, Jezioranski J, Grimard L, et al. Penile brachytherapy: results for 49 patients. Int J Radiat Oncol Biol Phys 2005;62:460-7. http://dx.doi.org/10.1016/i.i.irobp.2004.10.016

55. Korets R, Koppie TM, Snyder ME, et al. Partial penectomy for patients with squamous cell carcinoma of the penis: the Memorial Sloan-Kettering experience. Ann Surg Oncol 2007;14:3614-9. http://dx.doi. org/10.1245/s10434-007-9563-9

56. Minhas $\mathrm{S}$, Kayes 0 , Hegarty $\mathrm{P}$, et al. What surgical resection margins are required to achieve oncological control in men with primary penile cancer? BJU Int 2005;96:1040-3. http://dx.doi.org/10.1111/ j.1464-410X.2005.05769.x

57. Leije JA, Kerst JM, Bais E, et al. Neoadjuvant chemotherapy in advanced penile carcinoma. Eur Urol 2007:52:488-94. http://dx.doi.org/10.1016/i.eururo.2007.02.006

58. Graafland NM, Olmos RA, Meinhardt W, et al. Nodal Staging in Penile Carcinoma by Dynamic Sentinel Node Biopsy After Previous Therapeutic Primary Tumour Resection. Eur Urol 2010;58:748-51. http:// dx.doi.org/10.1016/i.eururo.2010.06.036. Epub 2010 Jul 12. 
59. Ornellas AA, Nobrega BL, Wei Kin Chin E, et al. Prognostic factors in invasive squamous cell carcinoma of the penis analysis of 196 patients treated at the Brazilian National Cancer Institute. J Urol 2008;180:1354-9. http://dx.doi.org/10.1016/i.juro.2008.06.028

60. Mistry T, Jones RW, Dannatt E, et al. A 10 year retrospective audit of penile cancer management in the UK. BJU Int 2007;100:1277-81. http://dx.doi.org/10.1111/i.1464-410X.2007.07168.x

61. Theron PD, Heyns C. Penectomy with simultaneous compared to deferred bilateral inguinal lymph node dissection for squamous cell carcinoma of the penis - evaluation of surgical complications. Afr J Urol 2007;13:8-16.

62. Thyavihallly YB, Tongaonkar $\mathrm{HB}$. Simultaneous inguinal lymph node dissection and penile surgery in patients with carcinoma of penis. J Urol 2007;177(Suppl) 332, Abst 1007.

63. Solsona E, Iborra I, Ricós JV, et al. Corpus cavernosum invasion and tumor grade in the prediction of lymph node condition in penile carcinoma. Eur Urol 1992;22:115-8.

64. Zhu Y, Zhang ZL, Ye DW, et al Predicting pelvic lymph node metastases in penile cancer patients. Onkologie 2008;31:37-41. http://dx.doi.org/10.1159/000112462

65. Catalona WJ. Modified inguinal lymphadenectomy for carcinoma of the penis with preservation of saphenous vein: technique and preliminary results. J Urol 1988; 140:306-10.

66. Protzel $C$, Alcaraz A, Horenblas $S$, et al. Lymphadenectomy in the surgical management of penile cancer. Eur Urol 2009;55:1075-88. http://dx.doi.org/10.1016/i.eururo.2009.02.021

67. Tobias-Machado M, Tavares A, Silva MN, et al. Can video endoscopic inguinal lymphadenectomy achieve a lower morbidity than open lymph node dissection in penile cancer patients. J Endourol 2008;22:1687-91. http://dx.doi.org/10.1089/end.2007.0386

68. Mclean $M, A k I A M$, Warde $P$, et al. The results of primary radiation therapy in the management of squamous cell carcinoma of the penis. Int I Radiat Oncol Biol Phys 1993;25:623-8. http://dx.doi. org/10.1016/0360-3016(93)90008-J

69. de Crevoisier R, Slimane K, Sanfilippo N, et al. Long-term results of brachytherapy for carcinoma of the penis confined to the glans (N- or NX). Int J Radiat Oncol Biol Phys 2009;74:1150-6. http://dx.doi. org/10.1016/i.ijrobp.2008.09.054

70. Crook JM, Jezioranski J, Grimard L, et al. Penile brachytherapy: results for 49 patients. Int J Radiat Oncol Biol Phys 2005;62:460-7. http://dx.doi.org/10.1016/i.iirobp.2004.10.016

71. Azrif M, Logue JP, Swindell R, et al. External-beam radiotherapy in TI-2 NO penile carcinoma. Clin Oncol (R Coll Radiol) 2006;18:320-5. http://dx.doi.org/10.1016/i.clon.2006.01.004

72. Gotsadze D, Matveev B, Zak B, et al. Is conservative organ-sparing treatment of penile carcinoma justified? Eur Urol 2000;38:306. http://dx.doi.org/10.1159/000020298

73. Crook J, Ma C, Grimard L. Radiation therapy in the management of the primary penile tumor: an update. World J Urol 2009;27:189. htrp://dx.doi.org/10.1007/s00345-008-0309-5

74. Crook J. Radiation therapy for cancer of the penis. Urol Clin North Am 2010;37:435-43. http://dx.doi. org/10.1016/i.ucl.2010.04.004

75. Rozan R, Albuisson E, Giraud B, et al. Interstitial brachytherapy for penile carcinoma: a multicentric survey (259 patients). Radiother Oncol 1995;36:83. http://dx.doi.org/10.1016/0167-8140(95)01574-2

76. Katz A, Eifel PJ, Jhingran $A$, et al. The role of radiation therapy in preventing regional recurrences of invasive squamous cell carcinoma of the vulva. Int J Radiat Oncol Biol Phys 2003;57:409-18. http:// dx.doi.org/10.1016/S0360-3016(03)00591-1

77. Ravi R, Chaturvedi HK, Sastry DV. Role of radiation therapy in the treatment of carcinoma of the penis. $\mathrm{Br}$ J Urol 1994;74:646-51. http://dx.doi.org/10.1111/i.1464-410X.1994.tb09199.x

78. Ravi R. Correlation between the extent of nodal involvement and survival following groin dissection for carcinoma of the penis. Br J Urol 1992;72:817-9.

79. Pagliaro LC, Crook J. Multimodality therapy in penile cancer: when and which treatments? World I Urol 2009;27:221-5. http://dx.doi.org/10.1007/s00345-008-0310-z

80. Hegarty PK, Kayes 0 , Freeman A, et al. A prospective study of 100 cases of penile cancer managed according to European Association of Urology Guidelines. BJU Int 2006;98:526-31. http://dx.doi. org/10.1111/i.1464-410X.2006.06296.X

81. von Minckwitz G, Untch M, Blohmer J-U, et al. Definition and impact of pathologic complete response on prognosis after neoadjuvant chemotherapy in various intrinsic breast cancer subtypes. J Clin Oncol 2012;30:1796-804. http://dx.doi.org/10.1200/JC0.2011.38.8595

82. Bormejo C, Busby JE, Spiess PE, et al. Neoadjuvant chemotherapy followed by aggressive surgical consolidation for metastatic penile squamous cell carcinoma. J Urol 2007;177:1335-8. http://dx.doi. org/10.1016/i.juro.2006.11.038

83. Pagliaro $\mathrm{LC}$, Williams DL, Daliani D, et al. Neoadjuvant paclitaxel, ifosfamide, and cisplatin chemotherapy for metastatic penile cancer: a phase II study. J Clin Oncol 2010;28:3851-7. http://dx.doi.org/10.1200/ $J C 0.2010 .29 .5477$

84. Pizzocaro G, Nicolai N, Milani A. Taxanes in combination with cisplatin and fluorouracil for advanced penile cancer: preliminary results. Eur Urol 2009;55:546-51. http://dx.doi.org/10.1016/i.eururo.2008.07.014

85. Pandey D, Mahajan V, Kannan RR. Prognostic factors in node-positive carcinoma. J Surg Oncol 2006; $93: 133-8$
86. Pizzocaro $G$, Piva L, Bandieramonte, $G$, et al. Up-to-date management of carcinoma of the penis. Eur Urol 1997;32:5-15.

87. Hakenberg OW, Protzel C. Chemotherapy in penile cancer. Ther Adv Urol 2012;4:133-8. http://dx.doi. org/10.1177/1756287212441235

88. Power DG, Galvin DJ, Cuffe $S$, et al. Cisplatin and gemcitabine in the management of metastatic penile cancer. Urol Oncol 2009;27:187-90. http://dx.doi.org/10.1016/j.urolonc.2007.10.015

89. Haas GP, Blumenstein BA, Gagliano RG, et al. Cisplatin, methotrexate and bleomycin for the treatment of carcinoma of the penis: a Southwest Oncology Group study. J Urol 1999;161:1823. http://dx.doi. org/10.1016/S0022-5347(05)68815-5

90. Theodore C, Skoneczna I, Bodrogi I, et al. A phase II multicentre study of irinotecan (CPT 11 ) in combination with cisplatin (CDDP) in metastatic or locally advanced penile carcinoma (EORTC PROTOCOL 30992). Ann Oncol 2008;19:1304-7. http://dx.doi.org/10.1093/annonc/mdn149

91. Pettaway CA, Pagliaro L, Theodore C, et al. Treatment of visceral, unresectable or bulky/unresectable regional metastases of penile cancer. Urology 2010;76:S58-65. http://dx.doi.org/10.1016/j.urotogy.2010.03.082

92. Di Lorenzo G, Federico $P$, Buonerba $C$, et al. Paclitaxel in pretreated metastatic penile cancer: final results of a phase 2 study. Eur Urol 2011;60:1280. http://dx.doi.org/10.1016/i.eururo.2011.08.028

93. Lont AP, Gallee MP, Meinhardt $W$, et al. Penis conserving treatment for $\mathrm{T} 1$ and $\mathrm{T} 2$ penile carcinoma: clinical implications of a local recurrence. J Urol 2006;176:575-80. http://dx.doi.org/10.1016/i. juro.2006.03.063

94. Wang J, Pettaway CA, Pagliaro LC. Salvage treatment for metastatic penile cancer after first-line chemotherapy with paclitaxel, ifosfamide, and cisplatin: Analysis of response and survival outcomes. I Clin Oncol 2012;30:Suppl 5; Abstr 340.

95. Zhu Y, Zhou XY, Yao XD, et al. The prognostic significance of p53, Ki-67, epithelial cadherin and matrix metalloproteinase-9 in penile squamous cell carcinoma treated with surgery. BJU Int 2007;100:204-8. http://dx.doi.org/10.1111/j.1464-410X.2007.06908.x

96. Bonner JA, Harari PM, Giralt J, et al. Radiotherapy plus cetuximab for squamous-cell carcinoma of the head and neck. N Engl J Med 2006;354:567-78. http://dx.doi.org/10.1056/NEJMoa053422

97. Carthon BC, Pettaway CA, Pagliaro LC. Epidermal growth factor receptor (EGFR) targeted therapy in advanced metastatic squamous cell carcinoma (AMSCC) of the penis. Proceeding of the American Society of Clinical Oncology Genitourinary Cancers Symposium; March 2010; San Francisco, Calif, USA. [abstract \#254].

98. Necchi A, Nicolai N, Colecchia $M$, et al. Proof of activity of anti-epidermal growth factor receptor-targeted therapy for relapsed squamous cell carcinoma of the penis. J Clin Oncol 2011;29:e650-2. http://dx.doi. org/10.1200/JC0.2011.34.8367

99. Romero FR, Romero KR, Mattos MA, et al. Sexual function after partial penectomy for penile cancer. Urology 2005; 66:1292-5. http://dx.doi.org/10.1016/j.urology.2005.06.081

100. Maddineni SB, Lau MM, Sangar VK. Identifying the needs of penile cancer sufferers: a systematic review of the quality of life, psychosexual and psychosocial literature in penile cancer. BMC Urol 2009;9:8. http://dx.doi.org/10.1186/1471-2490-9-8

101. Leijte JA, Kirrander P, Antonini N, et al. Recurrence patterns of squamous cell carcinoma of the penis: recommendations for follow-up based on a two-centre analysis of 700 patients. Eur Urol 2008:54:161-8. http://dx.doi.org/10.1016/i.eururo.2008.04.016

102. Schlenker $B$, Tilki $D$, Seitz $M$, et al. Organ-preserving neodymium-yttrium-aluminium-garnet laser therapy for penile carcinoma: a long-term follow-up. BJU Int 2010;106:786-90. http://dx.doi.org/10.1111/ j.1464-410X.2009.09188.x

103. Mobilio G, Ficarra V. Genital treatment of penile carcinoma. Curr Opin Urol 2001;11:299. http://dx.doi. org/10.1097/00042307-200105000-00010

104. Pizzocaro G, Piva L. Adjuvant and neoadjuvant vincristine, bleomycin and methotrexate for inguinal metastases from squamous cell carcinoma of the penis. Acta Oncol 1988;27:823-4. http://dx.doi. org $/ 10.3109 / 02841868809094366$

105. Di Lorenzo G, Buonerba C, Federico P, et al. Cisplatin and 5-fluorouracil in inoperable, stage IV squamous cell carcinoma of the penis. BJU Int 2012;110:E661-6. http://dx.doi.org/10.1111/i.1464410X.2012.11453.x

106. Gagliano RG, Blumenstein BA, Crawford ED, et al. cis-Diamminedichloroplatinum in the treatment of advanced epidermoid carcinoma of the penis: A Southwest Oncology Group Study. J Urol 1989;141:66-7.

Correspondence: Dr. Srikala S. Sridhar, Medical Oncologist, Princess Margaret Cancer Centre, Assistant Professor, Department of Medicine, University of Toronto, 5222 - 610 University Ave., Toronto, ON M5G 2M9; fax: 416-946-6546; srikala.ssidhar@uhn.on.ca 